\title{
Retroperitoneal Hemorrhage
}

National Cancer Institute

\section{Source}

National Cancer Institute. Retroperitoneal Hemorrhage. NCI Thesaurus. Code C26944.

Bleeding originating in the retroperitoneal area. 